\title{
Pathogenesis of and strategies for preventing Edwardsiella tarda infection in fish
}

Seong Bin Park', Takashi Aoki ${ }^{1,2}$ and Tae Sung Jung ${ }^{1 *}$

\begin{abstract}
Edwardsiella tarda is one of the serious fish pathogens, infecting both cultured and wild fish species. Research on edwardsiellosis has revealed that $E$. tarda has a broad host range and geographic distribution, and contains important virulence factors that enhance bacterial survival and pathogenesis in hosts. Although recent progress in edwardsiellosis research has enabled the development of numerous, highly effective vaccine candidates, these efforts have not been translated into a commercialized vaccine. The present review aims to provide an overview of the identification, pathology, diagnosis and virulence factors of $E$. tarda in fish, and describe recent strategies for developing vaccines against edwardsiellosis. The hope is that this presentation will be useful not only from the standpoint of understanding the pathogenesis of $E$. tarda, but also from the perspective of facilitating the development of effective vaccines.
\end{abstract}

\section{Table of contents}

1. Introduction

2. Identification and classification

3. Hosts

4. Pathology and diagnosis

5. Virulence factors

6. Vaccines

7. Concluding remarks

8. Competing interests

9. Authors' contributions

10. Acknowledgements

11. References

\section{Introduction}

Edwardsiellosis, caused by Edwardsiella tarda, has been reported worldwide in economically important fish species, including Japanese eel (Anguilla japonica), red sea bream (Pagrus major), yellowtail (Seriola quinqueradiata), channel catfish (Ictalurus punctatus), and turbot (Scophthalmus maximus) [1-4]. This infection also leads to serious economic losses in the aquaculture of olive flounder (Japanese flounder; Paralichthys olivaceus), the most important fish species in South Korean aquaculture,

\footnotetext{
* Correspondence: jungts@gnu.ac.kr

${ }^{1}$ Aquatic Biotechnology Center, College of Veterinary Medicine, Gyeongsang National University, Jinju 660-701, South Korea

Full list of author information is available at the end of the article
}

with production valued at 489.7 billion Korean Won (40 $922 \mathrm{MT}$ ), which corresponds to $56.5 \%$ of total fisheries production in 2010 [5-7].

Recent studies on vaccine development have applied a variety of antigen-preparation methods; however, commercial vaccines are not yet available. In addition, numerous studies have reported on virulence factors of $E$. tarda and immune responses of hosts. In the present study, the pathogenicities of $E$. tarda in fish that can be exploited to elicit effective protection strategies against edwardsiellosis will be discussed.

\section{Identification and classification}

The genus Edwardsiella is composed of three species, E. tarda, E. ictaluri, and E. hoshinae [8-10]. Fish are usually infected with E. tarda or E. ictaluri, whereas $E$. hoshinae infection is usually reported in reptiles and birds [11]. Panangala et al. [12] suggested that biochemical tests can differentiate E. tarda from E. ictaluri among bacteria isolated from freshwater fish based on the positive reaction of $E$. tarda in tests of indole production, methyl red reduction and hydrogen sulfide generation. In protein profiling of bacterial isolates using sodium dodecyl sulfate-polyacrylamide gel electrophoresis (SDS-PAGE) and Western blotting, the authors also demonstrated that E. ictaluri is more homogenously distributed than E. tarda. 
E. tarda was originally isolated from cultured Japanese eel (Anguilla japonica) in Japan in 1962 [1]. Subsequent findings for the bacterium were reported from snakes in Japan [13] and from human feces in the USA; the bacterium was designated E. tarda by Ewing et al. [8]. Although there was a move to change the epithet tarda to anguillimortiferum since it had been initially reported as Paracolobactrum anguillimortiferum [14], the bacterium is commonly named $E$. tarda because $P$. anguillimortiferum was not registered and the original culture was lost $[6,15]$.

E. tarda is a Gram-negative, short, rod-shaped, facultative anaerobic bacterium that measures about $2-3 \mu \mathrm{m}$ in length and $1 \mu \mathrm{m}$ in diameter [11]. It is usually motile, but isolates from red sea bream and yellowtail are non-motile [16]. This bacterium can survive at $0-4 \%$ sodium chloride, $\mathrm{pH} 4.0-10.0$, and 14$45^{\circ} \mathrm{C}$ [17]. The biochemical characteristics of E. tarda are catalase positive, cytochrome oxidase negative, production of indole and hydrogen sulfide, fermentation of glucose, and reduction of nitrate to nitrite [11]. However, several variations of biochemical tests have been found for ornithine decarboxylase, citrate utilization, hydrogen sulfide production, and fermentation of mannitol and arabinose. These discrepancies allow division into two groups: wild type and biogroup $1[8,9,18]$. The characteristics of wild-type E. tarda are negative for arabinose, mannitol and sucrose production, and positive for hydrogen sulfide production; the characteristics of biogroup 1 are the opposite.

Park et al. [19] demonstrated that E. tarda can be divided into four serotypes, A, B, C and D, using Oantigen extracts of 445 isolates from infected eel, water, and sediments. They suggested that $72 \%$ of isolates belonged to serotype $\mathrm{A}$, the most virulent group based on experimental challenge tests, whereas a subsequent study of E. tarda isolated from olive flounder revealed that all isolates were serotype A [20]. Another study established an E. tarda serotyping scheme comprising $61 \mathrm{O}$ groups and $45 \mathrm{H}$ antigens that is preferable for international applications [21].

Several important findings suggest that intra- and/or inter-specific variability exists among E. tarda strains. E. tarda isolated from humans could be differentiated from isolates from fish by RAPD (random amplified polymorphic DNA) analysis [22], and E. tarda isolated from freshwater fish or pond sediments showed diverse and/or homogeneous characteristics in plasmid profiling, ERIC-PCR (enterobacterial repetitive intergenic consensus-polymerase chain reaction), SDS-PAGE, and RFLP (restriction fragment length polymorphism) analyses of $16 \mathrm{~S}$ rDNA [12,23,24]. In addition, Western blot profiles of LPS (lipopolysaccharides) from E. tarda strains isolated from turbot and other fish revealed that only isolates from turbot were recognized by rabbit sera raised against the isolate from turbot [25]. Biochemical tests, protein profiling, LPS profiling, and RAPD analysis showed that E. tarda strains from olive flounder have highly homogeneous phenotypic and genotypic characteristics compared to isolates from Japanese eel (unpublished data).

\section{Hosts}

Since the first report of $E$. tarda infection in Japanese eel [1], E. tarda has been isolated from numerous marine and freshwater fishes, including barramundi (Lates calcarifer) [26], channel catfish [3], largemouth bass (Micropterus salmoides) [27], mullet (Mugil cephalus) [28], crimson sea bream (Evynnis japonica) [29], tilapia (Tilapia nilotica) [30], chinook salmon (Oncorhynchus tshawytscha) [31], red sea bream [2], yellow tail [2], olive flounder [32], common carp (Cyprinus carpio) [33], European sea bass (Dicentrarchus labrax) [34], turbot [4], Asian catfish (Claris batrachus) [35], brook trout (Salvelinus fontinalis) [36], Indian major carp (Catla catla) [37], rohu (Labeo rohita) [37], European eel (Anguilla anguilla) [38], and Far Eastern catfish (Silurus asotus) [39]. In addition, isolation of E. tarda has been reported in invertebrates [40], amphibians [40], reptiles $[13,26]$, birds $[27,41,42]$ and mammals, including humans, cattle, swine, dogs, and Weddell seals (Leptonychotes weddellii) [8,41-45]. These numerous reports indicate that E. tarda has a wide geographical distribution, even in Antarctica [42], and is an important pathogen in terms of public health, since it can progress as an epizootic and zoonotic bacterium [11].

\section{Pathology and diagnosis}

Edwardsiellosis in fish usually occurs under imbalanced environmental conditions, such as high water temperature, poor water quality, and high organic content [11]. Fish infected with $E$. tarda show abnormal swimming behavior, including spiral movement and floating near the water surface $[3,46]$. Although clinical signs vary after onset, fish infected with E. tarda show loss of pigmentation, exophthalmia, opacity of the eyes, swelling of the abdominal surface, petechial hemorrhage in fin and skin, and rectal hernia (Figure 1) $[6,35,46]$. Internally, watery and bloody ascites in the abdominal space and congested liver, spleen, and kidney are found $[46,47]$. Histopathological characteristics of edwardsiellosis in fish are suppurative interstitial nephritis, suppurative hepatitis, and purulent inflammation in the spleen [6,46-48]. Abscesses of various sizes, bacterial colonization, and infiltration of neutrophils and macrophages are found in the liver, spleen, and kidney $[6,47,48]$. Some remarkable pathological features have also been demonstrated in fish, such as dorsolateral petechial hemorrhage and abscesses in cutaneous lesions of channel 


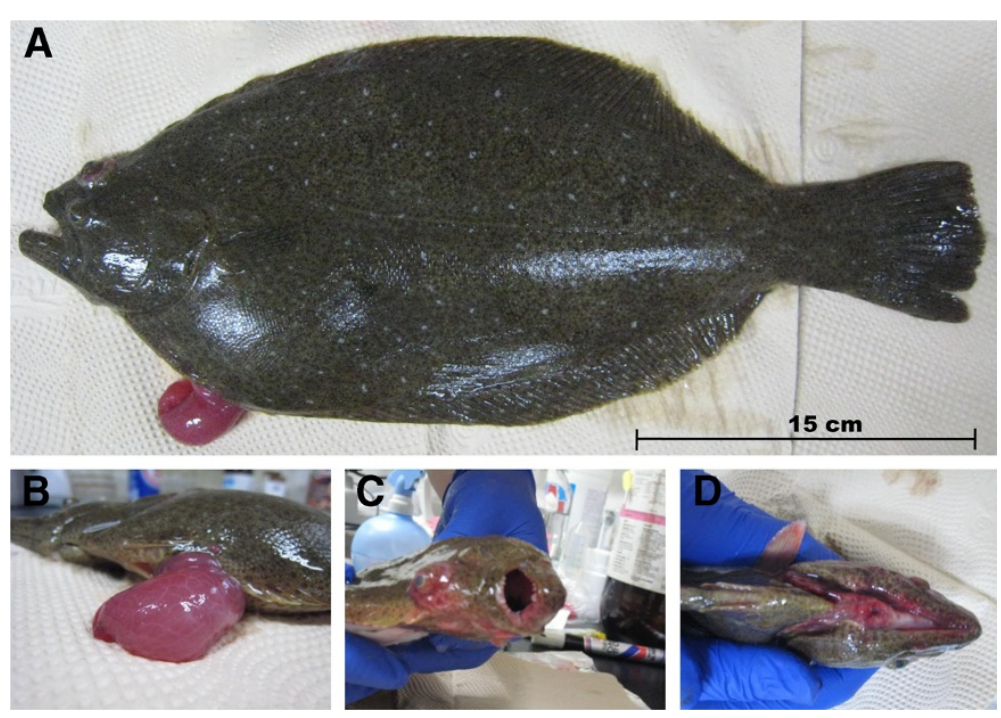

Figure 1 External signs of olive flounder infected with Edwardsiella tarda. A: External lesions of diseased fish. B: Abdominal distension and rectal hernia. C: Exophthalmia and opacity of the eye. D: Peripheral hyperemia in mandible lesion.

catfish [3,49]; hyperplasia, necrosis and inflammation in lateral line canals of striped bass [50]; and necrosis and aggregation of bacteria-laden macrophages in red sea bream [46]. However, the symptoms and pathological changes in fish are similar to those of other bacterial infections, including Aeromonas hydrophila, Vibrio anguillarum and Pseudomonas anguilliseptica; thus, other molecular or biochemical methods are recommended for diagnosis of E. tarda infection [51].

E. tarda is usually identified based on its unique biochemical characteristics after isolation on brain-heart infusion agar or tryptone soya agar from infected fish. Several studies have suggested that serological techniques are useful for diagnosis of E. tarda infection, including agglutination tests, enzyme linked immunosorbent assays (ELISA), and fluorescent antibody techniques [3,31,37]. Recently, PCR-based methods have been reported for accurate, sensitive, and differential diagnosis. Real-time PCR has been used to analyze the blood of oyster toadfish (Opsanus tau) infected with E. tarda [52], and the loopmediated isothermal amplification (LAMP) method is able to detect $E$. tarda in infected tissue samples and pond water [53]. Chang et al. [54] developed a multiplex nested PCR for four important fish pathogens in subtropical Asia that can simultaneously detect A. hydrophila, E. tarda, Photobacterium damselae and Streptococcus iniae from pure colonies and tissue homogenates. In addition, a primer set, evaluated using $53 \mathrm{E}$. tarda strains isolated from various sources and 18 representative strains of related and unrelated bacterial species, was shown capable of detecting two cells from pure culture and $3 \times 10^{2}$ cells in seeded turbot tissues [55].

\section{Virulence factors}

E. tarda survive in their host by utilizing several important substances and abilities that serve as virulence factors in the host (Figure 2). A study using green fluorescent protein (GFP) showed that both avirulent and virulent E. tarda are able to adhere to, invade, and replicate in the carp epithelial papilloma (EPC) cell line using host microfilaments and protein tyrosine kinase [56]. Histopathological and infection kinetics studies using GFP revealed that the gill, gastrointestinal tract, and body surface of blue gourami (Trichogaster trichopterus) are the sites of entry of the virulent strain [57].

Type III secretion system (T3SS) and type VI secretion system (T6SS) play important roles in adherence, penetration, survival, and replication of E. tarda in epithelial cells and phagocytes (Table 1). The T6SS of E. tarda comprises 16 genes, and 13 of the encoded proteins are involved in the secretion of $\operatorname{EvpP}$ (E. tarda virulence protein) [58]. Three proteins (EvpP, EvpI and EvpC) are secreted into the extracellular milieu, and the secretion of EvpC and EvpI are required for the secretion of EvpP [58]. The putative ATPase, EvpO, contains a Walker A motif, which possibly interacts with EvpA, EvpL, and EvpN [58]. T3SS is a multi-protein complex that is essential for host and pathogen interaction. The central component of T3SS is a needle complex, which is structurally similar to bacterial flagella, that spans the bacterial inner and outer membrane [59]. This needle can connect to the host cell membrane via the tip complex through the translocon, which can allow the delivery of bacterial effector proteins from an ATPase dependent manner [60]. In E. tarda, T3SS proteins include the $E$. 


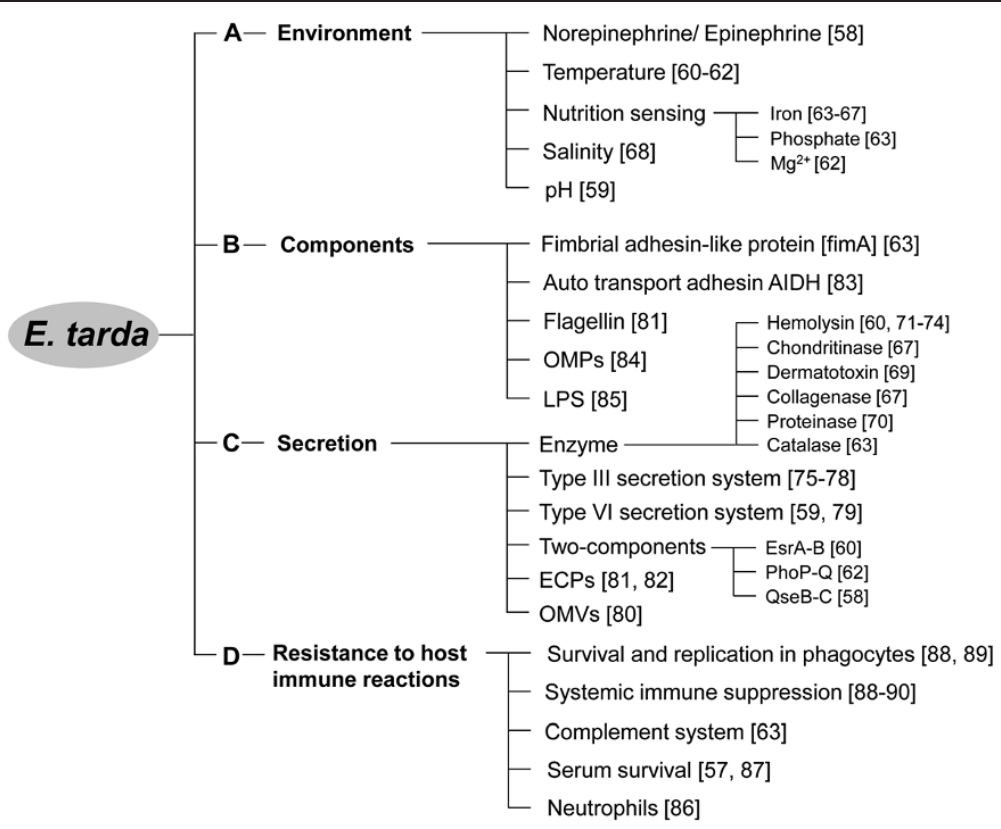

Figure 2 Factors contributing to Edwardsiella tarda survival and infection. A: E. tarda can survive by utilizing host and environmental elements. B and C: E. tarda possesses or secretes several virulence factors which may support multifactorial pathogenesis in the host. D: E. tarda is able to resist against host humoral and cellular immunities. Numbers in the brackets indicate the references.

tarda secretion system apparatus (EsaB and EsaN), effectors (EseB, EseC and EseD), chaperones (EscA, EscB and EscC), and regulators (EsrA, EsrB and EsrC) [60-62]. Proteomic studies have revealed that $\mathrm{EseB}, \mathrm{EseC}$ and EseD are the major ECP, and mutations of these genes in E. tarda reduces virulence compared to parental E. tarda [63].

Several reports found that motility-related proteins, such as flagellin and autotransport adhesin AIDA, a fimbrial adhesin-like protein, are important for attachment and penetration into the epithelial cells of hosts [63-65]. An E. tarda mutant containing a deletion of the ethA gene (hemolysin gene locus from E. tarda), regulated by the two-component system EsrA-EsrB and nucleid protein $\mathrm{Hha}_{\mathrm{Et}}$, shows reduced capacity to internalize into EPC cells [66]. Interestingly, a recent study showed that the qseB and qseC two-component system of E. tarda inhibits flagella biosynthesis and motility, and induces the expression of the T3SS after invasion into host cells [67]. These findings indicate that E. tarda is capable of modulating the expression of genes involved in adjusting to environmental changes, such as adaptation to intracellular living.

Indeed, $E$. tarda is able to survive and adapt to various host environmental conditions, including host hormonal change, temperature, $\mathrm{pH}$, salinity, and variations in several important nutritional elements, such as iron, phosphate, and $\mathrm{Mg}^{2+}$ [64-74]. The qseB and qseC twocomponent system, an important virulence regulator that contributes to intracellular replication and systemic infection, are able to regulate flagella motility and the intracellular expression of T3SS elements EseB and EsaC in response to eukaryotic hormone-like signals, such as epinephrine and norepinephrine [67]. The PhoP-PhoQ two-component system of $E$. tarda is able to sense changes in temperature and $\mathrm{Mg}^{2+}$ concentration and control the T3SS and T6SS via activation of esrB [70]. This study showed that a conformational change in PhoQ over a temperature range of $23-37^{\circ} \mathrm{C}$ and at low $\mathrm{Mg}^{2+}$ concentration causes PhoQ autophosphorylation and subsequent activation of PhoP, which promotes expression of esrB and leads to secretion of virulent proteins, whereas below $20^{\circ} \mathrm{C}$ or above $37^{\circ} \mathrm{C}$, no such conformational change in PhoQ takes place and the production of virulence proteins is decreased. Similarly, on the basis of observations of mutants containing an insertion of the pstSCAB-phoU operon, which is part of the phosphate regulon, Srinivasa Rao et al. [64] suggested that natural conditions of low inorganic phosphate in phagocytic and epithelial cells might stimulate virulent genes to promote survival and replication within the host. In another study, a high concentration of $\mathrm{NaCl}$ (3\%) was shown to induce hemagglutination activity, which correlated with the expression of fimbrial major subunit (FimA), a $19.3 \mathrm{kDa}$ protein; moreover, E. tarda enriched for this fimbrial protein showed higher virulence in challenge experiments compared to E. tarda raised in $0 \% \mathrm{NaCl}$ broth [75].

The ability of bacteria to acquire iron acquisition using the bacterial iron chelator, siderophore, is essential for 
Table 1 The virulence factors described in the present study

\begin{tabular}{|c|c|c|c|}
\hline Abbreviation & Name & Accession number & Function \\
\hline \multicolumn{4}{|c|}{ Type III secretion systems } \\
\hline EsaB & putative TTSS apparatus protein B & AAV69410 & apparatus \\
\hline $\mathrm{EsaC}$ & putative TTSS apparatus protein C & AAV69411 & apparatus \\
\hline EsaD & putative TTSS apparatus protein D & AAV69412 & apparatus \\
\hline EsaG & putative TTSS apparatus protein G & AAV69415 & apparatus \\
\hline $\mathrm{EsaH}$ & putative TTSS apparatus protein $\mathrm{H}$ & AAV69416 & apparatus \\
\hline Esal & putative TTSS apparatus protein I & AAV69417 & apparatus \\
\hline EsaJ & putative TTSS apparatus protein J & AAX76915 & apparatus \\
\hline Esak & putative TTSS apparatus protein $\mathrm{K}$ & AAX76913 & apparatus \\
\hline EsaL & putative TTSS apparatus protein $L$ & AAV69401 & apparatus \\
\hline EsaM & putative TTSS apparatus protein M & AAX76922 & apparatus \\
\hline EsaN & putative TTSS apparatus protein $\mathrm{N}$ & AAX76920 & apparatus \\
\hline EsaQ & putative TTSS apparatus protein Q & AAV69420 & apparatus \\
\hline EsaR & putative TTSS apparatus protein $\mathrm{R}$ & AAX76923 & apparatus \\
\hline Esas & putative TTSS apparatus protein $\mathrm{S}$ & AAV69419 & apparatus \\
\hline EsaT & putative TTSS apparatus protein $T$ & AAX76924 & apparatus \\
\hline EsaU & putative TTSS apparatus protein $U$ & AAV69421 & apparatus \\
\hline EsaV & putative TTSS apparatus protein $V$ & AAX76921 & apparatus \\
\hline EscA & putative TTSS chaperone protein A & AAV69403 & chaperone \\
\hline $\mathrm{EscB}$ & putative TTSS chaperone protein B & AAX76917 & chaperone \\
\hline $\mathrm{EscC}$ & putative TTSS chaperone protein $\mathrm{C}$ & AAV69402 & chaperone \\
\hline EseB & putative TTSS effector protein B & AAX76903 & effector \\
\hline EseC & putative TTSS effector protein C & AAV69404 & effector \\
\hline EseD & putative TTSS effector protein D & AAV69405 & effector \\
\hline EseE & putative TTSS effector protein E & AAV69406 & effector \\
\hline EseG & putative TTSS effector protein $\mathrm{G}$ & AAX76916 & effector \\
\hline EsrA & TTSS regulator protein $A$ & AAV69423 & regulator \\
\hline EsrB & TTSS regulator protein $B$ & AAX76904 & regulator \\
\hline EsrC & TTSS regulator protein $C$ & AAV69414 & regulator \\
\hline \multicolumn{4}{|c|}{ Type VI secretion systems } \\
\hline EvpA & E. tarda virulent protein $\mathrm{A}$ & AAR83927 & apparatus \\
\hline EvpB & E. tarda virulent protein $B$ & AAR83928 & apparatus \\
\hline EvpC & E. tarda virulent protein $C$ & AAR83929 & extracellular apparatus \\
\hline EvpD & E. tarda virulent protein $\mathrm{D}$ & AAR83930 & apparatus \\
\hline EvpE & E. tarda virulent protein $\mathrm{E}$ & AAS58123 & apparatus \\
\hline EvpF & E. tarda virulent protein $\mathrm{F}$ & AAS58124 & apparatus \\
\hline EvpG & E. tarda virulent protein $\mathrm{G}$ & AAS58125 & apparatus \\
\hline EvpH & E. tarda virulent protein $\mathrm{H}$ & AAS58126 & apparatus \\
\hline Evpl & E. tarda virulent protein I & ABW69081 & extracellular apparatus \\
\hline EvpJ & E. tarda virulent protein J & ABW69082 & apparatus \\
\hline EvpK & E. tarda virulent protein $\mathrm{K}$ & ABW69083 & apparatus \\
\hline EvpL & E. tarda virulent protein $L$ & ABW69084 & apparatus \\
\hline EvpM & E. tarda virulent protein $M$ & ABW69085 & apparatus \\
\hline EvpN & E. tarda virulent protein $N$ & ABW69086 & apparatus \\
\hline
\end{tabular}


Table 1 The virulence factors described in the present study (Continued)

\begin{tabular}{|c|c|c|c|}
\hline EvpO & E. tarda virulent protein $\mathrm{O}$ & ABW69087 & apparatus \\
\hline EvpP & E. tarda virulent protein $P$ & ABW69080 & extracellular apparatus \\
\hline \multicolumn{4}{|c|}{ The other proteins } \\
\hline AidA & putative autotransporter protein AidA & $\mathrm{BAH03175}$ & autotransporter adhesin \\
\hline HhaEt & a-hemolysin-modulator like protein & YP_003295064 & nucleoid-associated proteins \\
\hline EthA & E. tarda hemolysin A & BAA21097 & hemolysin \\
\hline EthB & E. tarda hemolysin B & BAA21096 & hemolysin activation/secretion \\
\hline QseB & DNA-binding transcriptional regulator QseB & ADO13165 & Quorum sensing (QS) system \\
\hline Qsec & sensor protein QseC & ADO24152 & Quorum sensing (QS) system \\
\hline PhoP & two-component regulator protein PhoP & ADB28435 & DNA-binding transcriptional regulator \\
\hline PhoQ & two-component sensor protein $\mathrm{PhoQ}$ & ADB28436 & sensor \\
\hline
\end{tabular}

the survival and replication of bacteria $[64,73]$. A natural mutant with lower siderophore production and a mutant with a gene encoding aryl sulfate sulfotransferase producing less siderophore showed significantly reduced virulence in $E$. tarda challenge experiments [72,73]. Recently, an $E$. tarda deletion mutant lacking the T6SS component evpP, which encodes a consensus ferric uptake regulator (Fur) box, was shown to exhibit low virulence in vivo and in vitro [74]. This finding might indicate that the EvpP protein in T6SS plays an important role in invasion mechanisms and thus may be a critical virulence factor.

It has been reported that E. tarda produces two kinds of hemolysin; one is a cell associated, iron-regulated hemolysin, encoded by eth $\mathrm{A}$ and $e t h \mathrm{~B}$, that is secreted as an extracellular protein (ECP) under iron-regulated conditions [76], and the other is an extracellular holeforming hemolysin distinct from EthA and EthB that is not regulated by iron [77-79]. A recent functional study demonstrated that EthA is critical for invasion in vivo and in vitro, and is regulated by the two-component system EsrA-EsrB and nucleid protein $\mathrm{Hha}_{\mathrm{Et}}$ [66]. Other enzymes, including catalase, chondroitinase, dermatotoxin, protease, and collagenase, are also important for the pathogenesis of $E$. tarda $[64,74,80,81]$.

Several studies have indicated that E. tarda is able to survive and replicate in phagocytes, leading to systemic infections [82-86]. Virulent E. tarda opsonized with serum of blue gourami can replicate within phagocytes and fails to induce an oxidative burst, possibly providing a mechanism for avoiding phagocyte-mediated killing [83]. A subsequent study revealed that the expression of the catalase (KatB) gene of E. tarda is responsible for the resistance to $\mathrm{H}_{2} \mathrm{O}_{2}$ and phagocyte-mediated killing [64]. Similarly, a comparison of the response of peritoneal macrophages from olive flounder to high- and lowvirulence $E$. tarda demonstrated that only the highly virulent strain is able to resist reactive oxygen species generated by macrophages, and survive and replicate within macrophages [84]. In a subsequent report, the authors of this latter study extended their results, demonstrating that virulent $E$. tarda elicit a significantly greater induction of nitric oxide and tumor necrosis factor (TNF)- $\alpha$ production by macrophages, actions that may account for the pathogenicity of E. tarda infection [85]. In addition, a study of $E$. tarda septicemia revealed that $E$. tarda induces systemic immunosuppression through lymphocyte apoptosis, which suppresses systemic immune responses during the initial stage of septicemia [86].

The host also seems to possess immune mechanisms for avoiding or resisting the propagation of E. tarda. An examination of the pathogenicity of motile and nonmotile E. tarda strains toward olive flounder, red sea bream, and yellow tail showed that all strains were virulent in the olive flounder and yellow tail, whereas only atypical strains showed mortality in the red sea bream [16]. These findings might indicate that immune mechanisms involved in recognition of and resistances against $E$. tarda vary among hosts. In zebra fish (Danio rerio), experimental infection with $E$. tarda resulted in an acute elevation of the inflammatory cytokines, interleukin-1 $\beta$ (IL-1 $\beta$ ) and TNF- $\alpha$ [87]. Indian major carp challenged with $E$. tarda exhibited a significant induction of immune responses and expression of several immune related genes, including IL-1 $\beta$, TNF- $\alpha$, inducible nitric oxide synthase (iNOS), complement component $\mathrm{C} 3, \beta_{2}$-microglobulin, CXCa, and C-type and G-type lysozyme [88]. T. Aoki and colleagues surveyed over a thousand genes in olive flounder infected with $E$. tarda using microarray analyses, identifying 36 genes that were differentially expressed between susceptible and resistant olive flounder groups [89-91]. Notably, 3 days post challenge, MHC class I antigen processing- and presenting-related genes were highly expressed in resistant groups, but susceptible groups showed high expression of genes involved in innate immune responses [90].

Understanding the virulence factors of $E$. tarda may inform the development of protection strategies against 
edwardsiellosis in fish. Recent progress in analytical methods, such as genomics and proteomics, has revealed important virulence factors, including T3SS, T6SS, and two-component systems (Figure 2). Verjan et al. demonstrated seven antigenic proteins, which were identified as lipoproteins, periplasmic proteins, exported, and secreted proteins [92]. Additional proteomic studies on outer membrane proteins (OMP), ECP, and outer membrane vesicles (OMV) may also contribute to the development of effective protection strategies against edwardsiellosis [60,63,65,69,93-98]. In addition, knowing the full genome sequence of $E$. tarda would enhance our understanding of the relationship between E. tarda and the host, and further the development of new prophylactic and therapeutic strategies for managing edwardsiellosis in fish [99].

\section{Vaccines}

A vaccine is by definition a biological preparation that improves immunity to a specific disease. The vaccine typically consists of several agents, such as weakened or killed forms of the microbe, its toxin or one of its surface proteins [100]. Numerous antigen preparation methods have been used to develop effective vaccines against edwardsiellosis, including formalin killed cells (FKC), LPS, ECP, live attenuated E. tarda, avirulent E. tarda, ghost cells, OMP, recombinant proteins, recombinant protein-expressing cells, OMV, and DNA vaccines (Table 2). Several early studies noted that immunization of Japanese eel with FKC or LPS exerted protective effects after challenge with a virulent strain of E. tarda [101-103]. However, another study reported no protective effect of

Table 2 Vaccine trials using a variety of antigen-preparation methods during the last decade

\begin{tabular}{|c|c|c|c|c|c|c|c|c|}
\hline No. & Antigen & Adjuvant & fish & Route & RPS (\%)* & Country & year & Ref. \\
\hline 1 & recombinant vaccine DnaJ & aluminum hydroxide & olive flounder & i.p. & 62 & China & 2011 & {$[106]$} \\
\hline 2 & recombinant vaccine OMP & - & common carp & i.p. & 54.3 & India & 2011 & [107] \\
\hline 3 & natural OMVs & - & olive flounder & i.p. & 70 & Korea & 2011 & {$[93]$} \\
\hline 4 & $\Delta$ alr $\Delta$ asd E. tarda & - & olive flounder & i.p. & 100 & Korea & 2011 & {$[108]$} \\
\hline 5 & recombinant vaccine rEta2 & aluminum hydroxide & olive flounder & i.p. & 83 & China & 2011 & {$[109]$} \\
\hline 6 & DNA vaccine pCEta2 & - & olive flounder & i.m. & 67 & China & 2011 & {$[109]$} \\
\hline 7 & recombinant vaccine pCEsa1 & - & olive flounder & i.p. & 57 & China & 2011 & {$[110]$} \\
\hline 8 & Esa1-expressing recombinant strain & aluminum hydroxide & olive flounder & $\mathrm{PO}$ & 52 & China & 2010 & {$[111]$} \\
\hline 9 & Esa1-expressing recombinant strain & aluminum hydroxide & olive flounder & i.p. & 79 & China & 2010 & {$[111]$} \\
\hline 10 & Live E22 & - & olive flounder & i.p. & 45 & Japan & 2010 & {$[112]$} \\
\hline 11 & DNA vaccine N163 & - & olive flounder & i.m. & 70.2 & China & 2010 & {$[113]$} \\
\hline 12 & recombinant vaccine scFv & Freund's incomplete adjuvant & Red drum & i.p. & 88 & China & 2010 & {$[114]$} \\
\hline 13 & recombinant vaccine EseD & Freund's complete adjuvant & turbot & i.p. & 62.5 & China & 2010 & {$[62]$} \\
\hline 14 & recombinant vaccine $\mathrm{Deg}_{\mathrm{Et}}$ & Freund's incomplete adjuvant & olive flounder & i.p. & 89 & China & 2010 & {$[81]$} \\
\hline 15 & Recombinant vaccine Et49 & Freund's incomplete adjuvant & olive flounder & i.p. & 47 & China & 2010 & {$[81]$} \\
\hline 16 & Live ATCC 15947 & - & olive flounder & i.p. & 100 & China & 2010 & {$[115]$} \\
\hline 17 & Extracted OMP & Freund's incomplete adjuvant & olive flounder & i.p. & 71 & China & 2010 & {$[97]$} \\
\hline 18 & recombinant vaccine Eta21 & Bacillus sp. strain B187 & olive flounder & i.p. & 69 & China & 2009 & {$[116]$} \\
\hline 19 & DH5a/pTAET21 & Bacillus sp. strain B187 & olive flounder & i.p. & 100 & China & 2009 & {$[116]$} \\
\hline 20 & DNA vaccine pEta6 & - & olive flounder & i.m. & 50 & China & 2009 & {$[117]$} \\
\hline 21 & recombinant vaccine Eta6 & Bacillus sp. strain B187 & olive flounder & i.p. & 53 & China & 2009 & {$[117]$} \\
\hline 22 & recombinant vaccine Et18 & Bacillus sp. strain B187 & olive flounder & i.p. & 61 & China & 2009 & {$[118]$} \\
\hline 23 & recombinant vaccine EseD & Bacillus sp. strain B187 & olive flounder & i.p. & 51.3 & China & 2009 & [118] \\
\hline 24 & Formalin killed ACC35.1 & Montanide ISA 763 AVG & turbot & i.p. & 100 & Spain & 2008 & {$[55]$} \\
\hline 25 & live, attenuated esrB mutant & - & turbot & i.p. & 93.3 & China & 2007 & {$[119]$} \\
\hline 26 & Ghost vaccine & - & olive flounder & $\mathrm{PO}$ & 85.7 & Korea & 2007 & {$[120]$} \\
\hline 27 & Ghost vaccine & - & tilapia & i.p. & 88.8 & Korea & 2006 & {$[121]$} \\
\hline 28 & 37 kDa OMP & - & olive flounder & i.p. & 70 & Japan & 2004 & {$[122]$} \\
\hline 29 & Formalin killed virulent bacterin & - & Indian major carp & immersion & 98 & India & 2002 & {$[37]$} \\
\hline
\end{tabular}

"_" means no adjuvant was added; i.p., intraperitoneal injection; i.m., intramuscular injection; PO, oral administration; ${ }^{\text {, }}$ relative percentage survival (RPS) calculating for vaccine efficacy (RPS = [1 minus vaccine group mortality/control group mortality $]$ x 100). 
FKC and LPS against E. tarda infection [104], possibly indicating the diverse antigenicity of $E$. tarda species [105]. Recent progress in vaccine preparation using diverse antigens has led to highly effective vaccines against $E$. tarda infection [106-122]. Several vaccine trials coupled with adjuvants have shown 100\% relative survival, and most evaluated trials were shown to produce significant protective effects (Table 2). Interestingly, more than $75 \%$ of the studies published in China, Japan and South Korea during the last decade have focused on the protective effects of vaccines in olive flounder, providing an indication that edwardsiellosis in olive flounder is a serious problem in Far East Asia and highlighting the urgent need to develop an effective, commercializable vaccine. Thus, to improve the efficacy of the vaccine, comprehensive understanding of bacterial pathogenesis, including intracellular surviving, host cell mediated-immune responses, and comparative epidemiological investigation on E. tarda originating from different finfish species is necessary. These efforts will allow for the identification of host pathogen cross-talk, which will lead to the identification of valuable vaccine candidates, such as a cocktail bacterin vaccine originating from different fish species, mutant vaccine made by deleting different genes compared with previous studies and DNA vaccine combined with several important multiple antigen genes.

\section{Concluding remarks}

E. tarda is a versatile Gram-negative bacterium that exhibits a broad geographical distribution and host range, and causes significant economic losses to the aquaculture industry. Despite limitations in this emerging field, recent studies on various virulence factors of $E$. tarda have enhanced our understanding of the pathogenesis of $E$. tarda, which adhere to, invade, and replicate in host cells and modulate their own gene expression to survive and adapt in fish. In addition, immune studies on edwardsiellosis applying proteomic and genomic approaches suggest that hosts sense the bacterium, induce inflammatory responses, and synergistically direct innate and adaptive immune responses against E. tarda infection. Furthermore, numerous studies on edwardsiellosis have reported highly efficacious vaccines, efforts that will encourage the development of a novel vaccine for use in aquaculture.

\section{Competing interests}

The authors declare that they have no competing interests.

\section{Authors' contributions}

SBP drafted the manuscript, tables, and figure. TA and TSJ critically evaluated and revised the manuscript for important intellectual content. All authors have read and approved the final manuscript.

\section{Acknowledgements}

This work was supported by a grant from the World Class University Program (no. R32-10253) funded by the Ministry of Education, Science and Technology, of South Korea.

\section{Author details}

'Aquatic Biotechnology Center, College of Veterinary Medicine, Gyeongsang National University, Jinju 660-701, South Korea. ${ }^{2}$ Consolidated Research Institute for Advanced Science and Medical Care (ASMeW), Waseda

University, 513, Wasedatsurumaki-cho, Shinjuku-ku, Tokyo 162-0041, Japan.

Received: 7 June 2012 Accepted: 7 September 2012

Published: 4 October 2012

\section{References}

1. Hoshina T: On a new bacterium, paracolobactrum anguillimortiferum n sp. Bull Jpn Soc Sci Fish 1962, 28:162-164.

2. Yasunaga N, Ogawa S, Hatai K: Characteristics of the fish pathogen Edwardsiella isolated from several species of cultured marine fishes. Bull Nagasaki Prefect Inst Fish 1982, 8:57-65.

3. Meyer FP, Bullock GL: Edwardsiella tarda, a new pathogen of channel catfish (Ictalurus punctatus). Appl Microbiol 1973, 25:155-156.

4. Nougayrede PH, Vuillaume A, Vigneulle M, Faivre B, Luengo S, Delprat J: First isolation of Edwardsiella tarda from diseased turbot (Scophthalmus maximus) reared in a sea farm in the Bay of Biscay. Bull Eur Assoc Fish Pathol 1994, 14:128-129.

5. Statistics Korea (KOSTAT): Republic of Korea: 2010 Survey on the status of fish culture; 2011. http://kostat.go.kr/portal/english/news/1/8/index.board? bmode $=$ download\&bSeq=\&aSeq=251088\&ord $=1$ [consulted 23 April 2012].

6. Egusa S: Some bacterial diseases of freshwater fishes in Japan. Fish Pathol 1976, 10:103-114.

7. Bang JD, Chun SK, Park SI, Choi YJ: Studies on the biochemical and serological characteristics of Edwardsiella tarda isolated from cultured flounder, Paralichthys olivaceus. J Fish Pathol 1992, 5:29-35.

8. Ewing WH, McWhorter AC, Escobar MR, Lubin AH: Edwardsiella, a new genus of Enterobacteriaceae based on a new species, E. Tarda. Int J Syst Evol Microbiol 1965, 15:33-38.

9. Grimont PAD, Grimont F, Richard C, Sakazaki R: Edwardsiella hoshinae, a new species of Enterobacteriaceae. Curr Microbiol 1980, 4:347-351.

10. Hawke JP, Mcwhorter A, Steigerwalt AG, Brenner DONJ: Edwardsiella ictaluri sp. nov., the causative agent of enteric septicemia of catfish. Int J Syst Evol Microbiol 1981, 31:396-400.

11. Woo PTK, Bruno DW: Fish diseases and disorders. Volume 3: viral, bacterial and fungal infections. In Edwardsiella septicaemias. $2^{\text {nd }}$ edition. Edited by Evans JJ, Klesius PH, Plumb JA, Shoemaker CA. Wallingford: CABI International; 2010:512-534.

12. Panangala VS, Shoemaker CA, McNulty ST, Arias CR, Klesius PH: Intra-and interspecific phenotypic characteristics of fish-pathogenic Edwardsiella ictaluri and E. tarda. Aquacult Res 2006, 37:49-60.

13. Sakazaki R: A proposed group of the family Enterobacteriaceae, the asakusa group. Int I Syst Evol Microbiol 1965, 15:45-47.

14. Sakazaki R, Tamura K: Priority of the specific epithet anguillimortiferum over the specific epithet tarda in the name of the organism presently known as Edwardsiella tarda. Int J Syst Bacteriol 1975, 25:219-220.

15. Farmer JJ III, Brenner DONJ, Clark WA: Proposal to conserve the specific epithet tarda over the specific epithet anguillimortiferum in the name of the organism presently known as Edwardsiella tarda: request for an opinion. Int J Syst Evol Microbiol 1976, 26:293-294.

16. Matsuyama T, Kamaishi T, Ooseko N, Kurohara K, lida T: Pathogenicity of motile and non-motile Edwardsiella tarda to some marine fish. Fish Pathol 2005, 40:133-136.

17. Ishihara S, Kusuda R: Growth and survival of Edwardsiella tarda bacteria in environmental water. Bull Jpn Soc Sci Fish 1982, 48:483-488.

18. Walton DT, Abbott SL, Janda JM: Sucrose-positive Edwardsiella tarda mimicking a biogroup 1 strain isolated from a patient with cholelithiasis. J Clin Microbiol 1993, 31:155-156.

19. Park S, Wakabayashi $H$, Watanabe $Y$ : Serotype and virulence of Edwardsiella tarda isolated from eel and their environment. Fish Pathol 1983, 18:85-89.

20. Rashid MM, Honda K, Nakai T, Muroga K: An ecological study on Edwardsiella tarda in flounder farms. Fish Pathol 1994, 29:221-227.

21. Tamura K, Sakazaki R, McWhorter AC, Kosako Y: Edwardsiella tarda serotyping scheme for international use. J Clin Microbiol 1988, 26:2343-2346

22. Nucci C, Da Silveira WD, da Silva Corrêa S, Nakazato G, Bando SY, Ribeiro MA, de Castro AF P: Microbiological comparative study of isolates of 
Edwardsiella tarda isolated in different countries from fish and humans. Vet Microbiol 2002, 89:29-39.

23. Maiti NK, Mandal A, Mohanty S, Mandal RN: Phenotypic and genetic characterization of Edwardsiella tarda isolated from pond sediments. Comp Immunol Microbiol Infect Dis 2009, 32:1-8.

24. Wei LS, Musa N: Phenotyping, genotyping and whole cell protein profiling of Edwardsiella tarda isolated from cultured and natural habitat freshwater fish. Am Eurasian J Agric Environ Sci 2008, 3:681-691.

25. Castro N, Toranzo AE, Barja JL, Nunez S, Magarinos B: Characterization of Edwardsiella tarda strains isolated from turbot, Psetta maxima (L.). J Fish Dis 2006, 29:541-547.

26. Iveson JB: Strontium chloride B and EE enrichment broth media for the isolation of Edwardsiella, Salmonella and Arizona species from tiger snakes. J Hyg (Lond) 1971, 69:323-330.

27. White FH, Simpson CF, Williams LE Jr: Isolation of Edwardsiella tarda from aquatic animal species and surface waters in Florida. J Wildl Dis 1973, 9:204-209.

28. Kusuda R, Toyoshima T, Iwamura Y, Sako H: Edwardsiella tarda from an epizootic of mullets (Mugil cephalus) in Okitsu Bay. Bull Jpn Soc Sci Fish 1976, 42:271-275.

29. Kusuda R, Itami T, Munekiyo M, Nakajima H: Characteristics of an Edwardsiella sp. from an epizootic of cultured crimson sea breams. Bull Jpn Soc Sci Fish 1977, 43:129-134.

30. Van Damme LR, Vandepitte J: Frequent isolation of Edwardsiella tarda and pleisiomonas shigelloides from healthy zairese freshwater fish: a possible source of sporadic diarrhea in the tropics. Appl Environ Microbiol 1980, 39:475-479.

31. Amandi A, Hiu SF, Rohovec JS, Fryer JL: Isolation and characterization of Edwardsiella tarda from fall chinook salmon (Oncorhynchus tshawytscha). Appl Environ Microbiol 1982, 43:1380-1384.

32. Nakatsugawa T: Edwardsiella tarda isolated from cultured young flounder. Fish Pathol 1983, 18:99-101.

33. Sae-Oui D, Muroga K, Nakai T: A case of Edwardsiella tarda infection in cultured colored carp Cyprinus carpio. Fish Pathol 1984, 19:197-199.

34. Blanch AR, Pinto RM, Jofre JT: Isolation and characterization of an Edwardsiella sp. strain, causative agent of mortalities in sea bass (Dicentrarchus labrax). Aquaculture 1990, 88:213-222.

35. Sahoo PK, Mukherjee SC, Sahoo SK: Aeromonas hydrophila versus Edwardsiella tarda: a pathoanatomical study in Clarias batrachus. J Aquacult 1998, 6:57-66.

36. Uhland FC, Hélie P, Higgins R: Infections of Edwardsiella tarda among brook trout in Quebec. J Aquat Anim Health 2000, 12:74-77.

37. Swain P, Nayak SK: Comparative sensitivity of different serological test for seromonitoring and surveillance of Edwardsiella tarda infection of Indian major carps. Fish Shellfish Immunol 2003, 15:333-340.

38. Alcaide E, Herraiz S, Esteve C: Occurrence of Edwardsiella tarda in wild European eels Anguilla anguilla from Mediterranean Spain. Dis Aquat Organ 2006, 73:77-81.

39. Yu JH, Han JJ, Park KS, Park KH, Park SW: Edwardsiella tarda infection in Korean catfish, silurus asotus, in a Korean fish farm. Aquacult Res 2009, 41:19-26.

40. Wyatt $L E$, Nickelson RI, Vanderzant C: Edwardsiella tarda in freshwater catfish and their environment. Appl Environ Microbiol 1979, 38:710-714.

41. Van Damme LR, Vandepitte J: Isolation of Edwardsiella tarda and plesiomonas shigelloides from mammals and birds in Zaire. Rev Elev Med Vet Pays Trop 1984, 37:145-151.

42. Leotta GA, Piñeyro P, Serena S, Vigo GB: Prevalence of Edwardsiella tarda in Antarctic wildlife. Polar Biol 2009, 32:809-812

43. Arambulo PV, Westerlund NC, Sarmiento RV: On the isolation of human enteric organisms from the bile of pigs and cattle. Acta Medica Philipp $1968,5: 84-86$

44. Mizunoe S, Yamasaki T, Tokimatsu I, Matsunaga N, Kushima H, Hashinaga K Kadota J: A case of empyema caused by Edwardsiella tarda. J Infect 2006 53:255-258.

45. Tacal JV Jr, Menez CF: The isolation of Edwardsiella tarda from a dog. Philipp J Vet Med 1969, 7:143-145.

46. Miyazaki T, Kaige N: Comparative histopathology of edwardsiellosis in fishes. Fish Pathol 1985, 20:219-227.

47. Miyazaki T, Egusa S: Histopathological studies of edwardsiellosis of the Japanese eel (Anguilla japonica), 1: suppurative interstitial nephritis form. Fish Pathol 1976, 11:33-43.
48. Miyazaki T, Egusa S: Histopathological studies of edwardsiellosis of the Japanese eel (Anguilla japonica), 2: suppurative hepatitis form. Fish Pathol $1976,11: 67-75$.

49. Darwish A, Plumb JA, Newton JC: Histopathology and pathogenesis of experimental infection with Edwardsiella tarda in channel catfish. J Aquat Anim Health 2000, 12:255-266.

50. Herman RL, Bullock GL: Pathology caused by the bacterium Edwardsiella tarda in striped bass. Trans Am Fish Soc 1986, 115:232-235.

51. Nishibuchi M, Muroga $K$, Jo $Y$ : pathogenic vibrio isolated from cultured eel. VI. Diagnostic tests for the disease due to the present bacterium. Fish Pathol 1980, 14:124-132.

52. Horenstein S, Smolowitz R, Uhlinger K, Roberts S: Diagnosis of Edwardsiella tarda infection in oyster toadfish (Opsanus tau) held at the Marine Resources Center. Biol Bull 2004, 207:171.

53. Savan R, Kono T, Itami T, Sakai M: Loop-mediated isothermal amplification: an emerging technology for detection of fish and shellfish pathogens. J Fish Dis 2005, 28:573-581.

54. Chang Cl, Wu CC, Cheng TC, Tsai JM, Lin KJ: Multiplex nested-polymerase chain reaction for the simultaneous detection of Aeromonas hydrophila, Edwardsiella tarda, Photobacterium damselae and Streptococcus iniae, four important fish pathogens in subtropical Asia. Aquacult Res 2009, 40:1182-1190

55. Castro N, Toranzo AE, Núñez S, Osorio CR, Magariños B: Evaluation of four polymerase chain reaction primer pairs for the detection of Edwardsiella tarda in turbot. Dis Aquat Organ 2010, 90:55-61.

56. Ling SHM, Wang XH, Xie L, Lim TM, Leung KY: Use of green fluorescent protein (GFP) to study the invasion pathways of Edwardsiella tarda in in vivo and in vitro fish models. Microbiology 2000, 146:7-19.

57. Ling $S H M$, Wang $X H$, Lim TM, Leung $K Y$ : Green fluorescent protein-tagged Edwardsiella tarda reveals portal of entry in fish. FEMS Microbiol Lett 2001, 194:239-243.

58. Zheng J, Leung KY: Dissection of a type VI secretion system in Edwardsiella tarda. Mol Microbiol 2007, 66:1 192-1206.

59. Zheng J, Tung SL, Leung KY: Regulation of a type III and a putative secretion system in Edwardsiella tarda by EsrC is under the control of a two-component system, EsrA-EsrB. Infect Immun 2005, 73:4127-4137.

60. Tan YP, Zheng J, Tung SL, Rosenshine I, Leung KY: Role of type III secretion in Edwardsiella tarda virulence. Microbiology 2005, 151:2301-2313.

61. Zheng J, Li N, Tan YP, Sivaraman J, Mok YK, Mo ZL, Leung KY: EscC is a chaperone for the Edwardsiella tarda type III secretion system putative translocon components EseB and EseD. Microbiology 2007, 153:1953-1962.

62. Wang B, Mo ZL, Xiao P, Li J, Zou YX, Hao B, Li GY: EseD, a putative T3SS translocon component of Edwardsiella tarda, contributes to virulence in fish and is a candidate for vaccine development. Mar Biotechnol (NY) 2010, 12:678-685.

63. Tan YP, Lin Q, Wang XH, Joshi S, Hew CL, Leung KY: Comparative proteomic analysis of extracellular proteins of Edwardsiella tarda. Infect Immun 2002, 70:6475-6480.

64. Srinivasa Rao PS, Lim TM, Leung KY: Functional genomics approach to the identification of virulence genes involved in Edwardsiella tarda pathogenesis. Infect Immun 2003, 71:1343-1351.

65. Sakai T, Matsuyama T, Sano M, lida T: Identification of novel putative virulence factors, adhesin AIDA and type VI secretion system, in atypical strains of fish pathogenic Edwardsiella tarda by genomic subtractive hybridization. Microbiol Immunol 2009, 53:131-139.

66. Wang X, Wang Q, Xiao J, Liu Q, Wu H, Zhang Y: Hemolysin EthA in Edwardsiella tarda is essential for fish invasion in vivo and in vitro and regulated by two-component system EsrA-EsrB and nucleoid protein HhaEt. Fish Shellfish Immunol 2010, 29:1082-1091.

67. Wang X, Wang Q, Yang M, Xiao J, Liu Q, Wu H, Zhang Y: QseBC controls flagellar motility, fimbrial hemagglutination and intracellular virulence in fish pathogen Edwardsiella tarda. Fish Shellfish Immunol 2011, 30:944-953

68. Leung KY, Siame BA, Snowball H, Mok YK: Type VI secretion regulation: crosstalk and intracellular communication. Curr Opin Microbiol 2011, 14:9-15.

69. Srinivasa Rao PS, Yamada Y, Tan YP, Leung KY: Use of proteomics to identify novel virulence determinants that are required for Edwardsiella tarda pathogenesis. Mol Microbiol 2004, 53:573-586

70. Chakraborty S, Li M, Chatterjee C, Sivaraman J, Leung KY, Mok YK: Temperature and Mg2+ sensing by a novel PhoP-PhoQ two-component 
system for regulation of virulence in Edwardsiella tarda. J Biol Chem 2010, 285:38876-38888.

71. Kokubo T, lida T, Wakabayashi H: Production of siderophore by Edwardsiella tarda. Fish Pathol 1990, 25:237-241.

72. Mathew JA, Tan YP, Srinivasa Rao PS, Lim TM, Leung KY: Edwardsiella tarda mutants defective in siderophore production, motility, serum resistance and catalase activity. Microbiology 2001, 147:449-457.

73. Igarashi A, lida T, Crosa JH: Iron-acquisition ability of Edwardsiella tarda with involvement in its virulence. Fish Pathol 2002, 37:53-58.

74. Wang X, Wang Q, Xiao J, Liu Q, Wu H, Xu L, Zhang Y: Edwardsiella tarda T6SS component evpP is regulated by esrB and iron, and plays essential roles in the invasion of fish. Fish Shellfish Immunol 2009, 27:469-477.

75. Yasunobu H, Arikawa Y, Fumtsuka-Uozumi K, Dombo M, lida T, Mahmoud MM, Okuda J, Nakai T: Induction of Hemagglutinating activity of Edwardsiella tarda by sodium chloride. Fish Pathol 2006, 41:29-34.

76. Janda JM, Abbott SL: Expression of an iron-regulated hemolysin by Edwardsiella tarda. FEMS Microbiol Lett 1993, 111:275-280.

77. Chen JD, Lai SY, Huang SL: Molecular cloning, characterization, and sequencing of the hemolysin gene from Edwardsiella tarda. Arch Microbiol 1996, 165:9-17.

78. Hirono I, Tange N, Aoki T: Iron-regulated haemolysin gene from Edwardsiella tarda. Mol Microbiol 1997, 24:851-856

79. Strauss EJ, Ghori N, Falkow S: An Edwardsiella tarda strain containing a mutation in a gene with homology to shlB and hpmB is defective for entry into epithelial cells in culture. Infect Immun 1997, 65:3924-3932.

80. Ullah MA, Arai T: Exotoxic substances produced by Edwardsiella tarda. Fish Pathol 1983, 18:71-75.

81. Jiao X, Zhang M, Cheng S, Sun L: Analysis of Edwardsiella tarda DegP, a serine protease and a protective immunogen. Fish Shellfish Immunol 2010, 28:672-677

82. Ainsworth JA, Dexiang C: Differences in the phagocytosis of four bacteria by channel catfish neutrophils. Dev Comp Immunol 1990, 14:201-209.

83. Srinivasa Rao PS, Lim TM, Leung KY: Opsonized virulent Edwardsiella tarda strains are able to adhere to and survive and replicate within fish phagocytes but fail to stimulate reactive oxygen intermediates. Infect Immun 2001, 69:5689-5697.

84. Ishibe K, Osatomi K, Hara K, Kanai K, Yamaguchi K, Oda T: Comparison of the responses of peritoneal macrophages from Japanese flounder (Paralichthys olivaceus) against high virulent and low virulent strains of Edwardsiella tarda. Fish Shellfish Immunol 2008, 24:243-251.

85. Ishibe K, Yamanishi T, Wang Y, Osatomi K, Hara K, Kanai K, Yamaguchi K, Oda T: Comparative analysis of the production of nitric oxide (NO) and tumor necrosis factor-[alpha](TNF-[alpha]) from macrophages exposed to high virulent and low virulent strains of Edwardsiella tarda. Fish Shellfish Immunol 2009, 27:386-389.

86. Pirarat N, Maita M, Endo M, Katagiri T: Lymphoid apoptosis in Edwardsiella tarda septicemia in tilapia, Oreochromis niloticus. Fish Shellfish Immunol 2007, 22:608-616.

87. Pressley ME, Phelan PE III, Eckhard Witten P, Mellon MT, Kim CH: Pathogenesis and inflammatory response to Edwardsiella tarda infection in the zebrafish. Dev Comp Immunol 2005, 29:501-513.

88. Mohanty BR, Sahoo PK: Immune responses and expression profiles of some immune-related genes in Indian major carp, Labeo rohita to Edwardsiella tarda infection. Fish Shellfish Immunol 2010, 28:613-621.

89. Matsuyama T, Fujiwara A, Nakayasu C, Kamaishi T, Oseko N, Hirono I, Aoki T: Gene expression of leucocytes in vaccinated Japanese flounder (Paralichthys olivaceus) during the course of experimental infection with Edwardsiella tarda. Fish Shellfish Immunol 2007, 22:598-607.

90. Yasuike M, Takano T, Kondo H, Hirono I, Aoki T: Differential gene expression profiles in Japanese flounder (Paralichthys olivaceus) with different susceptibilities to edwardsiellosis. Fish Shellfish Immunol 2010 29:747-752.

91. Aoki T, Hirono I, Kondo H, Hikima J, Jung TS: Microarray technology is an effective tool for identifying genes related to the aquacultural improvement of Japanese flounder, Paralichthys olivaceus. Comp Biochem Physiol Part D Genomics Proteomics 2011, 6:39-43.

92. Verjan N, Hirono I, Aoki T: Genetic loci of major antigenic protein genes of Edwardsiella tarda. Appl Environ Microbiol 2005, 71:5654-5658.

93. Park SB, Jang HB, Nho SW, Cha IS, Hikima J, Ohtani M, Aoki T, Jung TS: Outer Membrane Vesicles as a Candidate Vaccine against Edwardsiellosis. PLoS One 2011, 6:e17629.
94. Lee DC, Kim DH, Park SI: Effects of extracellular products of Edwardsiella tarda on the innate immunity in olive flounder Paralichthys olivaceus. Fish Pathol 2009, 45:17-23.

95. Kumar G, Rathore G, Sengupta U, Singh V, Kapoor D, Lakra WS: Isolation and characterization of outer membrane proteins of Edwardsiella tarda and its application in immunoassays. Aquaculture 2007, 272:98-104.

96. Vinogradov E, Nossova L, Perry MB, Kay WW: Structural characterization of the O-polysaccharide antigen of Edwardsiella tarda MT 108. Carbohydr Res 2005, 340:85-90.

97. Tang $X$, Zhan W, Sheng $X$, Chi H: Immune response of Japanese flounder Paralichthys olivaceus to outer membrane protein of Edwardsiella tarda. Fish Shellfish Immunol 2010, 28:333-343.

98. Kumar G, Sharma P, Rathore G, Bisht D, Sengupta U: Proteomic analysis of outer membrane proteins of Edwardsiella tarda. J Appl Microbiol 2010, 108:2214-2221.

99. Wang $Q$, Yang $M$, Xiao J, Wu H, Wang $X$, Lv $Y, X u L$, Zheng $H$, Wang S, Zhao $\mathrm{G}$ : Genome sequence of the versatile fish pathogen Edwardsiella tarda provides insights into its adaptation to broad host ranges and intracellular niches. PLoS One 2009, 4:e7646.

100. Robinson A, Hudson MJ, Cranage MP: Vaccine potocols. In Overview of Vaccines. 2nd edition. Edited by Ada G. Totowa: Humana Press; 2003:1-17.

101. Salati F, Kawai K, Kusuda R: Immune response of eel to Edwardsiella tarda lipopolysaccharide. Fish Pathol 1984, 19:187-192.

102. Gutierrez MA, Miyazaki T: Responses of Japanese eels to oral challenge with Edwardsiella tarda after vaccination with formalin-killed cells or lipopolysaccharide of the bacterium. J Aquat Anim Health 1994, 6:110-117.

103. Salati F, Kusuda R: Vaccine preparations used for immunization of eel Anguilla japonica against Edwardsiella tarda infection. Bull Jpn Soc Sci Fish 1985, 51:1233-1237.

104. Mekuchi T, Kiyokawa T, Honda K, Nakai T, Muroga K: Vaccination trials in the Japanese flounder against edwardsiellosis. Fish Pathol 1995, 30:251-256.

105. Newman SG: Bacterial vaccines for fish. Annu Rev Fish Dis 1993, 3:145-185.

106. Dang W, Zhang M, Sun L: Edwardsiella tarda DnaJ is a virulenceassociated molecular chaperone with immunoprotective potential. Fish Shellfish Immunol 2011, 31:182-188.

107. Maiti B, Shetty M, Shekar M, Karunasagar I, Karunasagar I: Recombinant outer membrane protein $\mathrm{A}(\mathrm{OmpA})$ of Edwardsiella tarda, a potential vaccine candidate for fish, common carp. Microbiol Res 2011, 167:1-7.

108. Choi SH, Kim KH: Generation of two auxotrophic genes knock-out Edwardsiella tarda and assessment of its potential as a combined vaccine in olive flounder (Paralichthys olivaceus). Fish Shellfish Immunol 2011, 31:58-65.

109. Sun Y, Liu CS, Sun L: Comparative study of the immune effect of an Edwardsiella tarda antigen in two forms: Subunit vaccine vs DNA vaccine. Vaccine 2011, 29:2051-2057.

110. Sun Y, Liu C, Sun L: Construction and analysis of the immune effect of an Edwardsiella tarda DNA vaccine encoding a D15-like surface antigen. Fish Shellfish Immunol 2010, 30:273-279.

111. Sun Y, Liu C, Sun L: Identification of an Edwardsiella tarda surface antigen and analysis of its immunoprotective potential as a purified recombinant subunit vaccine and a surface-anchored subunit vaccine expressed by a fish commensal strain. Vaccine 2010, 28:6603-6608.

112. Takano T, Matsuyama T, Oseko N, Sakai T, Kamaishi T, Nakayasu C, Sano M, lida T: The efficacy of five avirulent Edwardsiella tarda strains in a live vaccine against Edwardsiellosis in Japanese flounder, Paralichthys olivaceus. Fish Shellfish Immunol 2010, 29:687-693.

113. Jiao $X, \mathrm{Hu}$ Y, Sun L: Dissection and localization of the immunostimulating domain of Edwardsiella tarda FliC. Vaccine 2010, 28:5635-5640

114. Qin H, Jin X, Huang W, Liu Y: Production of an anti-idiotypic antibody single chain variable fragment vaccine against Edwardsiella tarda. Acta Biochim Biophys Sin (Shanghai) 2010, 42:129-136.

115. Cheng S, Hu Y, Zhang M, Sun L: Analysis of the vaccine potential of a natural avirulent Edwardsiella tarda isolate. Vaccine 2010, 28:2716-2721.

116. Jiao $X$, Dang W, Hu Y, Sun L: Identification and immunoprotective analysis of an in vivo-induced Edwardsiella tarda antigen. Fish Shellfish Immunol 2009, 27:633-638.

117. Jiao $X$, Zhang M, Hu Y, Sun L: Construction and evaluation of DNA vaccines encoding Edwardsiella tarda antigens. Vaccine 2009, 27:5195-5202 
118. Hou JH, Zhang WW, Sun L: Immunoprotective analysis of two Edwardsiella tarda antigens. J Gen App/ Microbiol 2009, 55:57-61.

119. Lan MZ, Peng X, Xiang MY, Xia ZY, Bo W, Jie L, Li XY, Jun ZP: Construction and characterization of a live, attenuated esrB mutant of Edwardsiella tarda and its potential as a vaccine against the haemorrhagic septicaemia in turbot, Scophthamus maximus (L.). Fish Shellfish Immunol 2007, 23:521-530.

120. Kwon SR, Lee EH, Nam YK, Kim SK, Kim KH: Efficacy of oral immunization with Edwardsiella tarda ghosts against edwardsiellosis in olive flounder (Paralichthys olivaceus). Aquaculture 2007, 269:84-88.

121. Kwon SR, Nam YK, Kim SK, Kim KH: Protection of tilapia (Oreochromis mosambicus) from edwardsiellosis by vaccination with Edwardsiella tarda ghosts. Fish Shellfish Immunol 2006, 20:621-626.

122. Kawai K, Liu Y, Ohnishi K, Oshima S: A conserved 37 kDa outer membrane protein of Edwardsiella tarda is an effective vaccine candidate. Vaccine 2004, 22:3411-3418.

doi:10.1186/1297-9716-43-67

Cite this article as: Park et al:: Pathogenesis of and strategies for

preventing Edwardsiella tarda infection in fish. Veterinary Research 2012 43:67

\section{Submit your next manuscript to BioMed Central and take full advantage of:}

- Convenient online submission

- Thorough peer review

- No space constraints or color figure charges

- Immediate publication on acceptance

- Inclusion in PubMed, CAS, Scopus and Google Scholar

- Research which is freely available for redistribution 